\title{
ENERGY RECOVERY FROM MUNICIPAL WASTE BASED ON MOVING GRATE TECHNOLOGY
}

\author{
Maciej Cyranka*, Michał Jurczyk
}

Department of Power Systems and Environmental Protection Facilities, AGH University of Science and Technology in Krakow

*Corresponding author: e-mail: cyranka@agh.edu.pl

\begin{tabular}{|c|c|}
\hline ARTICLE INFO & ABSTRACT \\
\hline $\begin{array}{l}\text { Article history: } \\
\text { Received: July } 2015 \\
\text { Received in the revised form: } \\
\text { September } 2015 \\
\text { Accepted: October } 2015\end{array}$ & $\begin{array}{l}\text { The objective of the paper was to analyse possibilities and advantages } \\
\text { of energy recovery from municipal solid waste during the thermal } \\
\text { treatment in boilers with a moving grate system. The state of the art of } \\
\text { Waste-to-Energy (WtE) boilers was investigated mainly by reviewing } \\
\text { papers published in scientific journals and at conferences but also by }\end{array}$ \\
\hline $\begin{array}{l}\text { Key words: } \\
\text { municipal waste, } \\
\text { incineration plant, } \\
\text { Waste-to-Energy, } \\
\text { thermal treatment, } \\
\text { energy recovery, } \\
\text { boiler, } \\
\text { moving grate }\end{array}$ & $\begin{array}{l}\text { shows the main aspects that determine the popularity of this type of } \\
\text { boilers as well as new solutions which greatly improve the process of } \\
\text { thermal treatment of waste. It proves that waste incineration boilers } \\
\text { based on the moving grate technology prevail mainly because of its } \\
\text { simplicity, reliability and effective energy generation to which special } \\
\text { attention was paid. Additionally, the article mentions how WtE boilers } \\
\text { are designed and operated to incinerate municipal waste with a great } \\
\text { variation in composition with simultaneous notable energy recovery } \\
\text { and low environmental impacts. Contemporary development of the } \\
\text { Polish WtE infrastructure can be a very important factor influencing } \\
\text { the national municipal waste management together with renewable } \\
\text { energy and energy efficiency policies. }\end{array}$ \\
\hline
\end{tabular}

\section{Introduction}

Beyond any doubt, the materials contained in the municipal waste stream, can be a valuable source of energy and materials. Modern waste energy recovery facilities (Waste-toEnergy) are widely considered by government agencies as effective municipal waste treatment solutions associated with production of energy, a part of which can be assumed as energy from renewable sources (EPRI, 2011).

The municipal waste chemical energy recovery process occurs in technical objects called Waste-to-Energy (WtE) plants used to reduce waste landfill burden, while providing electrical and heat energy production. Current expansion of the Polish WtE infrastructure, i.e. 6 facilities under construction right now (Białystok, Bydgoszcz, Konin, Kraków, Poznań, Szczecin), will improve the Polish waste management system and provide an additional source of energy for the national power grid. Moreover, the use of waste as an energy 
source will reduce the consumption of conventional fuels and contribute to the increase of Poland energy security.

All of the six aforementioned WtE plants under construction in Poland will conduct thermal processing of municipal waste through the combustion process. Characteristics of municipal waste affect the combustion process which differs significantly from the combustion of other conventional solid fuels like coal or lignite. This is due to the fact that municipal waste physicochemical properties show high variability in volume, including such parameters as chemical composition, grain size, heating value and moisture content. It is worth to note that the main purpose of conducting the thermal processing of municipal waste is to reduce waste volume and weight, but not energy production, as in case of boilers for conventional fuels.

\section{Waste-to-Energy boilers}

During thermal processing of municipal waste its energy is released and recovered in devices called boilers. In order to receive the energy released from the combustion of waste, it is necessary to use boiler systems that enable the transfer of energy to the circulating working medium. The process of energy recovery at modern WtE plants is achieved primarily through the use of steam boilers, i.e. those which use steam-water circuits (Lombardi et al., 2014). Nowadays, municipal waste is combusted mainly in two types of boilers, namely: moving grate boilers and fluidized bed boilers.

Moving grate boilers based on inclined reciprocating grates are currently the most widely used type of equipment for municipal waste energy recovery. The vast majority (approx. $87 \%$ - Europe (Lombardi et al., 2014), approx. 80\% - World (Klinghoffer, 2013) of modern municipal waste $\mathrm{WtE}$ plants, including all currently being built in Poland, assumes burning of waste in boilers equipped with moving grates. A schematic diagram of such a boiler is shown in Figure 1.

A moving grate principle of operation consists in a slow (the average waste residence time on the grate is approx. 1 hour (Kamuk, 2013)) movement of the processed waste in the layer, which is burned in subsequent phases, i.e.: drying, pyrolysis/gasification, combustion and burnout/sintering. Successful combustion of municipal waste is achieved by meeting the "3T" requirement (Time, Temperature and Turbulence) by the boiler design both regarding the solid mass and gaseous products of combustion (Rogoff and Screve, 2011; Cheremisinoff, 2003; IPPC, 2006):

Time - Residence times of municipal waste and gaseous products in boiler combustion and burnout zones should be sufficient to ensure maximal burnout of solid waste and to complete the oxidation reactions of organic volatiles in flue gases.

Temperature - usually exceeds $980^{\circ} \mathrm{C}$ within the combustion zone and is directly proportional to the solid waste residence time. It is necessary for $\mathrm{WtE}$ boilers to raise flue gases temperature, after the last injection of combustion air, to at least $850^{\circ} \mathrm{C}$ for two seconds (EU Directive 2000/76/EC).

Turbulence - adequate grate mechanism should provide moving the solid waste downward through the combustion zone to expose it to and mix it with primary air. While flue gases should be submitted to high turbulence in combustion and burnout zones in order to avoid dead spots or short residence time in the boiler. 


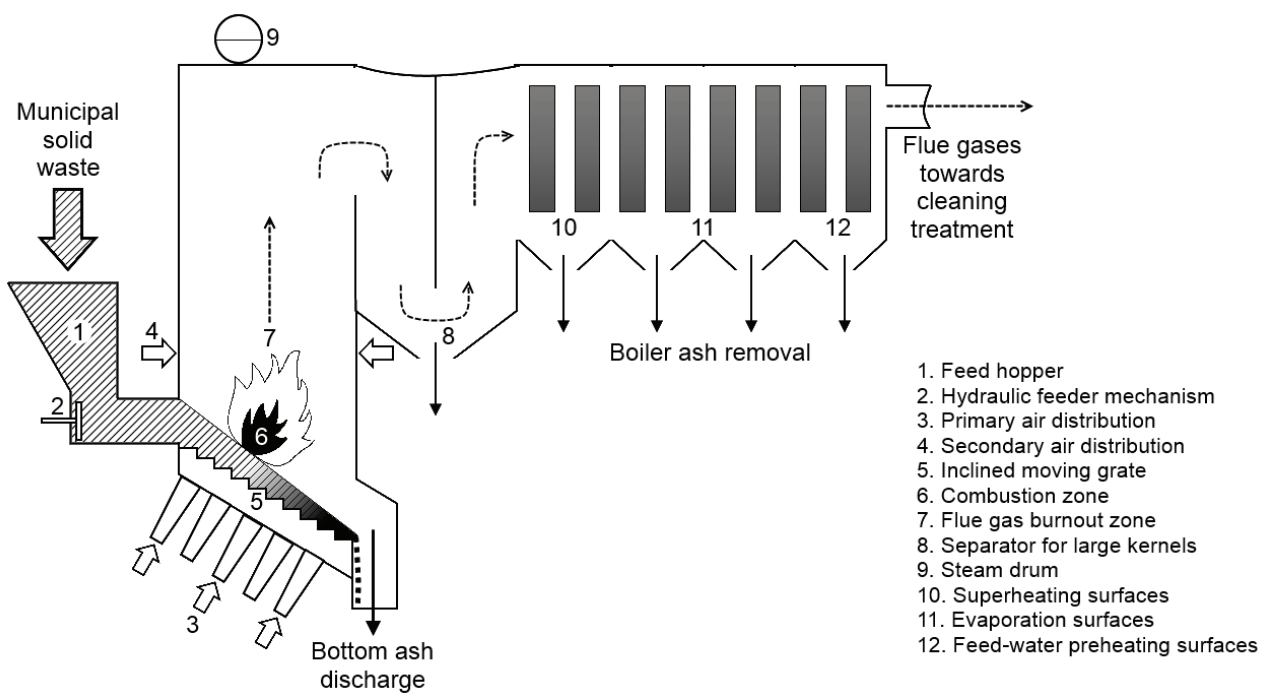

Figure 1. Example of moving grate boiler for waste incineration

The focus on above parameters together with proper distribution of combustion air supply is a very important condition for stable and efficient operation of the WtE boilers. The efficiency of the processes and changes occurring in the boiler enclosure have a direct impact not only on the energy efficiency of energy recovery, but also on the pollutants formation.

\section{Scope of moving grate technology}

High popularity and wide distribution of moving grate technology for municipal waste thermal treatment are dictated by, inter alia, its advanced stage of development, simplicity, reliability and the best energetic effects. Average efficiency of energy production in European $\mathrm{WtE}$ plants is $26.1 \%$ in case of electricity production only, $77.2 \%$ in case of heat production only and $52.1 \%$ in case of combined heat and power production (Reimann, 2012). Comparison of electrical energy efficiency values of different waste thermal treatment processes is presented in table 1 .

None of the alternative technology is able to guarantee the energy efficiency rate achievable for plants based on waste combustion on moving grate, especially considering annual availability. While fluidized bed boilers, which are second most commonly used waste incineration technology (10\% - among European incinerators (Lombardi, 2014), are oriented principally on burning pre-processed municipal waste or particular groups of waste with adequate and uniform particle size, such as fuel from waste (RDF/SRF), industrial waste or sewage sludge.

However, adaptability of the moving grate incineration technology to be used in a wide range of composition and physicochemical properties of processed waste can be assumed as its main advantage. This advantage is particularly important in the case of the thermal treatment of municipal waste, which has a high variability of composition depending on the 
waste generation location and the current season. WtE facilities based on moving grates allow burning of various varieties of waste, including: municipal waste, industrial waste (e.g. from plastics industry), biodegradable and agricultural waste (straw and wood), packaging waste and sometimes hazardous waste (e.g. medical waste).

Table 1.

Overview of the net electrical efficiencies of waste thermal treatment technologies

\begin{tabular}{lccc}
\hline $\begin{array}{l}\text { Reference plant, City } \\
\text { (Country) }\end{array}$ & Technology & $\begin{array}{c}\text { Net electrical } \\
\text { efficiency }\end{array}$ & Source \\
\hline AlterNRG, Utashinai (J) & Plasma gasification & $18.6 \%$ & \\
Ebara, New York (US) & Gasification & $13-15 \%$ & \\
Energos, Sarpsborg (N) & Gasification & $18.5 \%{ }^{*}$ & (Lamers et al., \\
TechTrade, Burgau (D) & Pyrolysis & $24.6 \%$ & $2013)$ \\
Thermoselect (CH) & Pyrolysis and gasification & $19.0 \%{ }^{*}$ & \\
Tpf Basse Sambre, Keflavik (IS) & Pyrolysis and gasification & $18.0 \%$ & \\
RRRF, Robbins (USA) & Circulating fluidized bed & $23.0 \%$ & (Granatstein, \\
TIRMadrid, Madrid (E) & Bubbling fluidized bed & $19.4 \%$ & 2001) \\
ZTPOK, Kraków (PL) & Moving grate & $21.0 \%{ }^{*}$ & (Socotec, 2009) \\
Riverside, London (GB) & Moving grate & $27.0 \%$ & (Takano, 2015) \\
Afval Energie Bedrijf & Moving grate & $>30.0 \%{ }^{* *}$ & (Van Berlo, \\
Amsterdam (NL) & & & $2007)$ \\
\hline
\end{tabular}

*Theoretical or project value

${ }^{* *}$ The maximum electric efficiency of $\mathrm{WtE}$ plant reported in the literature is $31.2 \%$ for Amsterdam plant optimized for production of electric energy (Lichtenbelt, 2014)

Based on information in literature, the following advantages for waste incineration plants based on the moving grates technology are provided (Umweltbundesamt, 2010; Consonni et al., 2005; EPRI, 2011; Fodor and Klemes, 2012; Kamuk, 2013; Lombardi et al., 2014; Velzy and Grillo, 2007):

- a significant reduction in volume of waste (approx. 90\%),

- reduction of the reactivity and environmental impact of waste,

- neutralization and disinfection of organic and inorganic pollutants contained in waste,

- ability to perform energy recovery process, which increases the profitability and environmental benefits of WtE plant,

- thanks to the very effective flue gas cleaning systems, incinerators may be located near inhabited areas which reduces costs of transport and improves the distribution of the produced energy (the current annual average emissions are even 100 times below the limits),

- high availability (modern incinerators offer availability greater than $90 \%$ ),

- wide range of the cost-effective boilers, from approximately 10 up to 50 tons $\cdot \mathrm{h}^{-1}$,

- minimization of the necessary waste pre-treatment (over 1000 from 1200 waste incineration plants in the world do not process their waste before combustion on the moving grate), 
- cooperation with material recovery processes as a part of a reasonable and comprehensive waste management system,

- suitable for processing residues from sorting and mechanical biological treatment processes (approx. 8\% incinerators in Europe process residues after sorting),

- possibility of ferrous and non-ferrous metals separation from the bottom ash,

- further utilization possibility for generated solid residues (biologically stable) in construction industry,

- many years of experience (the first grate incinerators were built in the late $19^{\text {th }}$ century);

- optimal use of available land area.

Summarizing the aforementioned issues concerning the moving grate technology and great popularity is justified. The share of the moving grate technology in the municipal waste treatment infrastructure in some countries is presented in table 2.

Table 2.

Number of incineration plants in different countries with the share of moving grate technology

\begin{tabular}{|c|c|c|c|c|}
\hline Country & $\begin{array}{c}\text { WtE share in } \\
\text { waste management }\end{array}$ & $\begin{array}{l}\text { Number of WtE } \\
\text { plants }\end{array}$ & $\begin{array}{l}\text { Moving grate } \\
\text { technology share }\end{array}$ & Source \\
\hline Austria & $30 \%$ & $11^{*}$ & $73 \%$ & \\
\hline France & $34 \%$ & $123^{*}$ & $84 \%$ & \\
\hline Germany & $38 \%$ & $65^{*}$ & $85 \%$ & $\begin{array}{c}\text { (ISWA, 2012) and } \\
\text { (CEWEP, 2012) }\end{array}$ \\
\hline Netherlands & $39 \%$ & $13^{*}$ & $77 \%$ & \\
\hline Sweden & $49 \%$ & $24^{*}$ & $71 \%$ & \\
\hline USA & $7 \%$ & 86 & $70 \%$ & $\begin{array}{l}\text { (Themelis and } \\
\text { Mussche, 2013) and } \\
\text { (Michaels, 2010) }\end{array}$ \\
\hline Japan & $58 \%$ & 310 & $84 \%$ & $\begin{array}{l}\text { (Themelis and } \\
\text { Mussche, 2013) }\end{array}$ \\
\hline China & $16 \%$ & $77^{* *}$ & $60 \%$ & (Nelles et al., 2011) \\
\hline
\end{tabular}

${ }^{*}$ The municipal WtE plants with the published data and with operational capacity exceeding $10,000 \mathrm{t} \cdot \mathrm{year}^{-1} \mathrm{were}^{\mathrm{s}}$ included

${ }^{* *}$ China is currently experiencing a significant increase in the WtE market. Only in 2011 there were 22 new plants put into operation (Howes and Warren, 2013)

Certainly, thermal treatment of municipal waste in the moving grate boilers has also some disadvantages. For instance, it is necessary to equip every incinerator with a flue gas treatment system from which residues (dust and ashes) must be landfilled at hazardous waste landfill. Moreover, the need of environmental protection in the waste incineration plant generates high operating costs which constitute main financial costs in this technology. However most importantly, according to the required hierarchy of waste management (EU Directive 2008/98/EC), the energy recovery from waste should be taken into account after consideration of other possible forms of treatment, such as reuse or material recycling. 
Maciej Cyranka, Michał Jurczyk

\section{Modern moving grate boilers solutions}

Current trends of $\mathrm{WtE}$ boilers are oriented mainly at the increase of the energy recovery, and reduce the amount of produced solid, liquid and gas pollutants. The potential for effective recovery in waste incineration plants (as well as any power plant using a steam-water cycle) can be improved by increasing the thermodynamic parameters of the produced live steam. However, due to the corrosive nature of the gases emitted during the combustion of waste, steam temperatures and pressures, standard for conventional plants cannot be obtained within $\mathrm{WtE}$ boilers. The modern standard for waste incineration plants is the use of steam at temperatures approx. $400^{\circ} \mathrm{C}$ and a pressure of approx. $4 \mathrm{MPa}$ (Van Berlo, 2012; Umweltbundesamt, 2010; IPPC 2006; Kamuk, 2013; Lombardi et al., 2014). These parameters constitute a compromise between energy recovery efficiency and acceptable hightemperature corrosion of the heat exchange surfaces within a boiler (Van Berlo, 2012).

The most important modern solutions and methods for improving performance of the moving grate boilers are summarized below:

- Avoiding corrosion - Corrosion is a very important factor influencing availability and energy efficiency of $\mathrm{WtE}$ boilers. Modern corrosion reducing methods areas follows (according to Grillo, 2013; Lee, 2009; Van Berlo, 2012; Adams et al., 2004):

- The selection of appropriate metals for construction of the boiler - i.e. the use of steel alloys with nickel, chromium and molybdenum.

- The use of protective coatings - as Inconel Alloy 625, on boiler surfaces with the highest temperature (membrane walls and superheaters).

- Sprayed coatings - use of supersonic flame spraying, thermal spraying and plasma spraying may increase the lifespan of protection layers.

- Proper design of the boiler geometry - in order to obtain a uniform distribution of the flue gas velocity, smooth transition between boiler passes and minimize collision velocity of flue gases with boiler surfaces.

- Methods to reduce the $\mathrm{Cl} / \mathrm{S}$ ratio in the flue gases - Achieved, inter alia, by ensuring the appropriate temperature, mixing and oxygen content of the flue gases.

- Avoiding the heat concentration points by ensuring a uniform temperature distribution - achieved by good mixing of the flue gases, the adequate process control and by ensuring as far as possible homogeneous waste stream.

- Injection of chemicals into the combustion zones - the purpose of such injection $(\mathrm{Ca}(\mathrm{OH}) 2$ or $\mathrm{Mg}(\mathrm{OH}) 2)$ is to reduce the concentration of $\mathrm{HCl}$ in exhaust gas and to reduce the build-up of impurities on heat transfer surfaces and reduce their corrosivity.

- Keppel Seghers BOILER PRISM - it involves the placement of the dynamic mixer in the burnout zone of the boiler (i.e. with secondary air injection). This component reduces the flue gas temperature, provides the optimum mixing and also allows for a more uniform injection of the secondary air.

- Optimization of the air distribution - Usually, the primary and secondary air shares are respectively $60 \%$ and $40 \%$ (Kamuk, 2013). Most of the modern municipal waste incinerators work with excess air of between $50 \%$ and $100 \%$. Excess air should be maximally restricted so as to ensure a high efficiency of energy recovery. However the excess air reduction should be reasonably controlled, since its excessive reduction may lead to an increase in the intensity of the corrosion and elevate emission levels of products of incomplete combustion (PICs). 
- Flue gas recirculation - Recirculated flue gas can increase efficiency and lower emissions through cooling the flue gases without the demand for more air. Additionally economic benefits are increased by the lower capital costs associated with the smaller installed capacity of the flue gas cleaning equipment. While environmental benefits are increased by decrease in gaseous pollution resulting from the smaller flow rate of flue gases (Liuzzo et al., 2007). Additionally, flue gas recirculation is a measure used to eliminate corrosion by influencing flow dynamics by enhancing flue gas mixing.

- Advanced combustion control (ACC) - Achieving optimal combustion conditions with minimal pollutant emissions by the use of automatic control of various parameters of the $\mathrm{WtE}$ process. An example of such solution is The Inova Grate by Hitachi Zosen Inova company which, thanks to the grate division on 4 independent zones, allows independent control of position, inclination, motion and air distribution for each zone separately, making it easier for system to response on fluctuations in waste fuel properties (HZI, 2014). Newest ACC solutions have developed measurement and monitoring systems based on an infrared camera mounted in a boiler, capable of providing a thermal mapping across the grate. Objectives of such sensors are to maintain a uniform flue gas temperature profile and to control the combustion air distribution. However, the main objectives of using the ACC systems are to (Madsen, 2007): fix position of main combustion and burnout zones, reduce fluctuations of process parameters (e.g. steam flow, temperatures etc.) and increase annual waste throughput and also lifetime of boiler.

- Computational fluid dynamics (CFD) - CFD is tool used for solving the fluid flow equations with numerical methods that helps to provide insight into waste incineration processes. Generally, CFD may be applied to provide insight in cases of troubleshooting and also it may be used to provide the basis for selection of better alternatives during the design of new or modified boilers (Stehlik, 2009). Additionally CFD gives the possibility of checking the boiler design for achieving " $3 \mathrm{~T}$ " requirement (time, temperature, and turbulence) to provide efficient and environmentally safe waste incineration.

- Optimal selection of heat exchangers - Standard heat transfer from flue gases to steam-water circuit in the moving grate boilers is realized by the use of the membrane walls in the boiler first pass and tube bundles in further passes (shown in Figure 1). Modern WtE plants try to optimize efficiency of energy conversion by using feedwater preheaters, preheating air for combustion and sometimes by the intermediate reheat concept (IPPC, 2006). Steam reheating can be done by additional bundle in the boiler passes or by the use of external superheating to circumvent the corrosion by using heat from another fuel to superheat the steam (Van Berlo, 2012). However, the use of heat exchangers in the first passes of boiler (i.e. Heat transfer by a radiation zone) requires the use of measures reducing corrosion, erosion and deposition of pollutants.

- Flue gases flow or combustion zone separation - Major portions of the corrosive species are released on the front of the grate (where the waste reaches after feeder) and rear parts of the grate are characterized by releasing much less corrosive combustion products. That fraction which exhibits low chlorine concentration could then be used in a high temperature superheater to increase the steam temperature and thereby the electricity efficiency of WtE plant. Above concept is used by SteamBoost ${ }^{\mathrm{TM}}$ technology by Babcock \& Wilcox Vølund Company (Madsen, 2008). Whereas the Karlsruhe Institute of Technology research center has proposed a new technology for WtE plants based on extracting flue gases prior entering the burnout zone. This fuel gases passes bypass sys- 
tem equipped with subsequently arranged sections of: gas cooling, gas cleaning, combustion and further superheating of the regenerated steam from the main boiler (Bogalea and Viganòa, 2014).

- Improved cleaning methods - Fouling heat transfer surfaces is a serious problem for WtE plants. Clean heat transfer surfaces result in better heat exchange and may also reduce the risk of dioxin formation in the boiler. Still improving methods for cleaning boiler without need to shut it down, are for example: mechanical rapping, soot-blowing by steam injection or explosive cleaning (IPPC, 2006).

\section{Summary}

Energy recovered from municipal waste, is, without doubt, a very valuable source for the national power grid, much more beneficial from the environment point of view than energy produced from fossil fuels. This article presents the factors which determine the fact that the incineration of municipal waste with the moving grate is widespread among facilities carrying out energy recovery from waste.

The grate technology has a wide range of experience and knowledge. Moreover, original and innovative solutions aimed at improving are still being developed. In order to reach the desired benefits from the thermal treatment of municipal waste like significant energy recovery and low environmental impact, an incinerator must be based on the properly selected and optimized boiler. Projects of modern boilers in waste incinerators are taking into account very wide criteria related not only to potential energy efficiency, but above all the impact of incineration on the environment.

\section{References}

Adams, B., Peeters, K., Eeraerts, D., Diederen, H.S.W., Wijnhoven, J.P.F. (2004). Seghers boiler prism: a proven primary measure against high temperature boiler corrosion. Savannah, 12th Annual North American Waste to Energy Conference, 17-19.05.2004.

Bogalea, W., Viganòa, F. (2014). A preliminary comparative performance evaluation of highly efficient Waste-to-Energy plants. Energy Procedia, 45, 1315-1324.

CEWEP - Confederation of European Waste-to-Energy Plants (2012). Recycling and Waste-toEnergy in combination for sustainable waste management. CEWEP, Brussels. Obtained from: http://www.cewep.eu/m_1038.

Cheremisinoff, N.P. (2003). Handbook of Solid Waste Management and Waste Minimization Technologies. 1 Edition. Butterworth-Heinemann. ISBN 0-7506-7507-1.

Consonni, S., M. Giugliano, M., Grosso, M. (2005). Alternative strategies for energy recovery from municipal solid waste. Part A: mass and energy balances. Waste Management, 25, 123-135.

European Union (2000). Directive 2000/76/EC of the European Parliament and the Council of 4 December 2000 on the incineration of waste. Official Journal of the European Communities, $28 / 12 / 2000$.

European Union (2008). Directive 2008/98/EC of the European Parliament and the Council of 19 November 2008 on Waste and Repealing Certain Directives. Official Journal of the European Union, $22 / 11 / 2008$.

EPRI - Electric Power Research Institute (2011). Waste-to-Energy Technology - Opportunities for Expanding Renewable Generation \& Reducing Carbon Emissions. EPRI, Palo Alto. Obtained from: http://www.epri.com/abstracts/Pages/ProductAbstract.aspx?ProductId=0000000001022361. 
Fodor, Z., Klemes, J.J. (2012). Waste as alternative fuel - Minimising emissions and effluents by advanced design. Process Safety and Environmental Protection, 90, 263-284.

Granatstein, D. (2011). Technoeconomic Assessment of Fluidized Bed Combustors as Municipal Solid Waste Incinerators. Reno, 16th ASME International Conference on Fluidized Bed Combustion, 13-16.05.2001. Obtained from: http://ieabioenergytask36.org/documents/studies/Summary of Six Case Studies.pdf.

Grillo, L. (2013). Municipal solid waste (MSW) combustion plants. [w]: Klinghoffer N. Waste to Energy Conversion Technology, Woodhead Publishing, ISBN 978-0-85709-011-9.

Howes, P., Warren, K. (2013). Integration of Thermal Energy Recovery into Solid Waste Management. Paris. Obtained from: http://www.ieabioenergytask36.org/vbulletin/attachment.php?att achmentid $=382 \& \mathrm{~d}=1396884184$.

Madsen, O. H. (2007). Next Generation of Waste Fired Power Plants. Miami, NAWTEC 15, 21 23.05.2007. Obtained from: http://www.volund.dk/Waste to Energy/media/Downloads/Conference $\% 20$ papers $\% 20-\% 20$ WTE/NAWTEC $\% 2015 \% 20-\% 20 \mathrm{Next} \% 20$ Generation $\% 20$ of $\% 20$ waste-fired $\% 20$ power\%20plants.ashx.

Madsen, O. H., Bøjer, M., Jensen, P. A., Dam-Johansen, K. (2008). High Electrical Efficiency by Dividing The Combustion Products. Philadelphia, NAWTEC16, 19-21.05.2008. Obtained from: http://www.volund.dk/Waste to_Energy/ /media/Downloads/Conference\%20papers\%20-\%20 WTE/NAWTEC $\% 2016 \% 2020$ High\%20electrical\%20efficiency $\% 20$ by $\% 20$ dividing $\% 20$ the $\% 20 \mathrm{c}$ ombustion\%20products.ashx.

HZI - Hitachi Zosen Inova AG, (2014). The Inova Grate - New standard in combustion technologist. Booklet, Zurich. Obtained from: http://www.hz-inova.com/cms/wp-content/uploads/2014/ 11/HZI Grate.pdf.

IPPC - Integrated Pollution Prevention and Control (2006), BREF, Reference Document on the Best Available Techniques for Waste Incineration. IPPC, Seville. Obtained from: http://eippcb.jrc.ec. europa.eu/reference/BREF/wi_bref_0806.pdf.

ISWA - the International Solid Waste Association (2012). Waste-to-Energy State-of-the-Art-Report Statistics, 6th Edition. ISWA, Copenhagen. Obtained from: http://www.waste-managementworld.com/content/dam/wmw/online-articles/documents/2013/ISWA_WtE_State_of_theArt_Report 201208 FV.pdf.

Kamuk, B. (2013), Waste to Energy in low and middle income countries. ISWA, Vienna. Obtained from: https://www.iswa.org/index.php?eID=tx_iswaknowledgebase_download\&document Uid.

Klinghoffer, N. (2013). Waste to energy (WTE): an introduction. [w]: Klinghoffer N. Waste to Energy Conversion Technology, Woodhead Publishing, ISBN 978-0-85709-011-9.

Lamers, F., Fleck, E., Pelloni, L., Kamuk, B. (2013). White Paper on Alternative Waste Conversion Technologies. ISWA. Obtained from: www.iswa.org/index.php? $\mathrm{eID}=\mathrm{tx}$ iswaknowledgebase download\&documentUid $=3155$.

Lee, S. H. (2009). High-Temperature Corrosion in Waste-to-Energy Boilers. New York, Columbia University. Obtained from: http://www.seas.columbia.edu/earth/wtert/sofos/lee phd thesis.pdf.

Lichtenbelt, E. (2014). Clean and valuable solutions for your waste streams. AEB Amsterdam, Utrecht. Obtained from: www.vvm.info/file.php?id=2740.

Liuzzo, G., Verdone, N., Bravi, M. (2007). The benefits of flue gas recirculation in waste incineration. Waste Management, 27, 106-116.

Lombardi, L., Carnevale, E., Corti, A. (2014). A review of technologies and performances of thermal treatment systems for energy recovery from waste. Waste Management, 37, 26-44.

Michaels, T. (2010). The 2010 ERC Directory of Waste-to-Energy Plants. The Energy Recovery Council, Arlington. Obtained from: http://www.energyrecoverycouncil.org/userfiles/ile/ERC_ 2010 Directory.pdf. 
Nelle,s M., Dorn, T., Wu, K., Cai, J. (2011). Status and perspectives of waste incineration in China. Hong Kong, International Conference on Solid Waste 2011 - Moving Towards Sustainable Resource Management, 2-6.05.2011. Obtained from: http://www.iswa.org/uploads/tx _ iswaknow ledgebase/10_Thermal_Technology.pdf.

Reimann, D. (2012). Energy Report III (Status 2007-2010). CEWEP, Bamberg. Obtained from: $\mathrm{http} / / / \mathrm{www} . c e w e p . e u / \mathrm{m} 1069$.

Rogoff, M., Screve, F. (2011). Waste-to-Energy: Technologies and Project Implementation. 2nd Edition, Elsevier, ISBN 978-1-4377-7871-7.

Socotec, (2009). Raport o oddzialywaniu przedsięwzięcia pn."Budowa Zakładu Termicznego Przeksztatcania Odpadów przy ul. Giedroycia w Krakowie" jako element projektu "Program gospodarki odpadami komunalnymi w Krakowie". Socotec, Warszawa. Obtained from: www.khk. krakow.pl/kiovwdkjovxfbd3a9.file.pdf.

Stehlik, P. (2009). Contribution to advances in waste-to-energy technologies. Journal of Cleaner Production, 17, 919-931.

Takano, M. (2015). Grate Combustion for Mixed MSW. Hyderabad, 3rd International Brainstorming Workshop on "Sustainable Municipal Solid Waste Management in India", 29-30.01.2015. Obtained from: http://www.iea.org/media/topics/energyefficiency/emak/wshop6/S2.5 Makoto Takano.pdf.

Themelis, N.J., Mussche, C. (2013). Municipal solid waste management and Waste-to-Energy in the United States, China and Japan. Houthalen-Helchteren, $2^{\text {nd }}$ International Academic Symposium on Enhanced Landfill Mining, 14-16.10.2013. Obtained from: http:/www.elfm.eu/ Uploads/ELFM/ FILE 73D907E9-8225-4B93-91F8-10F71F59B793.PDF.

Umweltbundesamt. (2010). Sprawdzone metody gospodarowania odpadami komunalnymi. Obtained from: http://www.umweltbundesamt.de/sites/default/files/podrecznik.pdf.

Van Berlo, M. (2007). Unleashing the power in waste - A great potential that should not be wasted $\mathrm{CO} 2$ and other performance indicators for WtE. Malmo, ISWA BEACON conference. Obtained from: http://www.iswa.org/uploads/tx iswaknowledgebase/wte6.pdf.

Van Berlo, M. (2012). Waste-to-Energy Facilities as Power Plants. [w]: Kaltschmitt M. et al. Renewable Energy Systems, Springer, ISBN 978-1-4614-5819-7.

Velzy, C., Grillo, L. (2007). Waste-to-Energy Combustion. [w]: Kreith F., Goswami D.Y. Handbook of Energy Efficiency and Renewable Energy, CRC Press, ISBN 978-0-8493-1730-9. 


\section{ODZYSK ENERGII Z ODPADÓW KOMUNALNYCH OPARTY NA TECHNOLOGII KOTŁÓW Z RUSZTEM RUCHOMYM}

Streszczenie. Celem niniejszego artykułu było przeanalizowanie możliwości oraz korzyści związanych $\mathrm{z}$ odzyskiem energii $\mathrm{z}$ odpadów komunalnych podczas ich termicznego przekształcania w kotłach z rusztem ruchomym. Współczesny stan techniki kotłów do odzysku energii z odpadów badano głównie interpretując dokumenty, opublikowane w czasopismach naukowych i materiałach pokonferencyjnych, ale również biorąc pod uwagę raporty różnych instytucji badawczych. $\mathrm{W}$ artykule przedstawiono główne aspekty, które decydują o popularności tego typu kotłów, a także nowe rozwiązania, które znacznie usprawniają proces termicznego przekształcania odpadów. Wykazano, że dominującym typem kotłów do spalania odpadów komunalnych są właśnie kotły oparte na technologii rusztów ruchomych, co wynika głównie z ich prostoty, niezawodności oraz efektywnego wytwarzania energii, na co zwrócono szczególną uwagę. Dodatkowo artykuł porusza zagadnienia związane z projektowaniem i eksploatacją kotłów spalających zmienne w składzie odpady komunalne, przy równoczesnym zapewnieniu efektywnego odzysku energii oraz niskiego wpływu na środowisko naturalne. Współczesny rozwój polskiej infrastruktury spalarni odpadów może być bardzo ważnym czynnikiem wpływającym na krajową gospodarkę odpadami komunalnymi oraz na politykę odnawialnych źródeł energii i efektywności energetycznej.

Słowa kluczowe: odpady komunalne, spalarnia odpadów, odzysk energii, termiczne przekształcanie, kocioł, ruszt ruchomy 